\title{
VARIASI WAKTU DAN CARA PENGOLAHANSEBELUM DIKONSUMSI TERHADAP PENURUNAN KANDUNGAN ASAM SIANIDA PADA VARIETAS REBUNG BAMBU AMPEL (Bambusa vulgaris Schrad. ex Wendl.)
}

\author{
[Variation of Time and Preparation Method Before The Ampel Bamboo Shoot \\ (Bambusa vulgaris Schrad. ex Wendl.) is Consumed Towards Decreasing of Cyanide \\ Content]
}

\author{
Ceria Arun Venagaya ${ }^{{ }^{\star}}$, Syariful Anam ${ }^{1}$, Yonelian Yuyun ${ }^{1}$ \\ 1) Jurusan Farmasi, Fakultas Mipa Universitas Tadulako, Palu \\ Jl. Soekarno Hatta Km.9, Kampus Bumi Tadulako Tondo Palu, Telp. 0451- 422611
}

Diterima 27 April 2017, Disetujui 7 Agustus 2017

\begin{abstract}
The common bamboo (Bambusa vulgaris Schrad. ex Wendl.) shoot has nutrition content, yet it also contains anti-nutrition substance which is harmful to the health, namely hydrogen cyanide (HCN), that the right way in processing is required to reduce and even eliminate the cyanide content before the bamboo is consumed. In this research, the bamboo shoot was processed through steeping and running water, followed by variation of boiling time. The research findings indicate that the lowest reduction in cyanide level is in steeping and boiling for 5 minutes at $68 \mathrm{ppm}$, while the biggest reduction of cyanide level occurred in treatment combination of the bamboo shoot washed with the running water and the boiling in 120 minutes at $656.33 \mathrm{ppm}$. Based on the research findings, it can be concluded that the boiling time affected the cyanide level of the bamboo shoot, in which the longer boiling time, the lower cyanide level.
\end{abstract}

Key Words: Cyanide, Bamboo Shoot, Common Bamboo (Bambusa vulgaris Schrad. ex Wendl.)

\begin{abstract}
ABSTRAK
Rebung bambu ampel (Bambusa vulgaris Schrad. ex Wendl.) memiliki kandungan nutrisi, namun di samping itu juga rebung mengandung unsur anti nutrisi yang membahayakan kesehatan yaitu kandungan hidrogen sianida $(\mathrm{HCN})$ sehingga dibutuhkan cara pengolahan yang benar agar kandungan sianida dapat dikurangi bahkan dapat dihilangkan sebelum dikonsumsi. Pada penelitian ini rebung diolah dengan cara perendaman dan air mengalir yang dilanjutkan dengan variasi waktu perebusan. Hasil penelitian ini menunjukan bahwa penurunan kadar sianida terendah yaitu pada perendaman dan perebusan selama 5 menit sebesar $68 \mathrm{ppm}$ sedangkan penurunan kadar sianida yang paling besar terjadi pada kombinasi perlakuan rebung yang dicuci dengan air mengalir dan perebusan selama 120 menit sebesar 656,33 ppm. Berdasarkan hasil penelitian ini dapat disimpulkan bahwa waktu perebusan mempengaruhi kadar sianida rebung, semakin lama waktu perebusan kadar sianida semakin menurun.
\end{abstract}

Kata kunci : Sianida, Rebung, Bambu Ampel (Bambusa vulgaris Schrad. ex Wendl.) 


\section{PENDAHULUAN}

Rebung merupakan batang muda dari bambu berukuran 8-12 cm, berbentuk lonjong, dengan warna batang hijau kekuningan serta memiliki bau yang khas (Anonim, 2014).Ukuran rebung di setiap lokasi berbeda-beda tergantung pada beberapa faktor seperti tempat tumbuhnya, nutrisi tanah, curah hujan, suhu, serta kesuburan tanah.

Pola pemanfaatan rebung di sebagian besar daerah menunjukkan bahwa rebung dapat di konsumsi dengan cara sepertidirebus, fermentasi, atau dalam bentuk obat-obatan. Rebung tidak hanya sekedar makanan masyarakat Sulawesi Tengah tetapi rebung kaya akan kandungan gizi yang terdapat dalamnya antara lain, kalium, karbohidrat, serat, vitamin, asam amino, antioksidan seperti flavonoid, fenol, dan steroid.

Selain memiliki kandungan nutrisi, rebung juga mengandung unsur-unsur anti nutrisi yang dapat membahayakan kesehatan yang disebut dengan kandungan Hidrogen Sianida (HCN) sehingga dibutuhkan cara pengolahan yang benar agar kandungan anti nutrisi dapat di kurangi bahkan dapat dihilangkan sebelum dikonsumsi.

Sianida yaitu suatu cairan tidak berwarna yang mudah menguap, mendidih pada $26^{\circ} \mathrm{C}$, dengan toksisitas yang sangat tinggi (LD: 1-2 mg/kg BB oral) dan memiliki bau yang khas (Schmitz et al., 2004). Konsumsi senyawa ini secara berlebihan atau terus menerus akan berbahaya bagi tubuh manusia.

Gejala keracunan akibat mengkonsumsi sianida yang terkandung dalam makanan antara lain radang kerongkongan, pusing, lemas, muntahmuntah,pingsan, dan kejang perut (Pambayun, 2007).

Berbagai penelitian dilakukan untuk dapat mengetahui cara dalam mengurangi bahkan menghilangkan kadar sianida pada rebung. Menurut Kanchan et al. (2015) Penurunan tingkat sianida dapat dicapai dengan beberapa metode pengolahan seperti mengiris, mengupas, perendaman air mengalir, fermentasi, memasak (perebusan, pengukusan), pengeringan dan pengalengan.

\section{METODE PENELITIAN}

\section{Alat dan Bahan}

Alat yang digunakan dalam penelitian ini anta Alat yang digunakan dalam penelitian yaitu neraca analitik, cawan porselin, desikator, wajan, hot plate, oven, batang pengaduk, corong, statif dan klem, buret, gelas kimia (pyrex®), (erlenmeyer (pyrex®), pipet ukur, pipet tetes, saringan, gelas ukur, dan 1 set alat evaporator, Labu ukur.

Bahan yang digunakan yaitu sampel rebung, air mineral akuades, kertas perkamen garam dapur, natrium hidroksida $(\mathrm{NaOH}) \quad 2,5 \%$, Amonium Hidroksida $\left(\mathrm{NH}_{4} \mathrm{OH}\right)$, Kalium dikromat $\left(\mathrm{K}_{2} \mathrm{CrO}_{7}\right)$, Natrium klorida ( $\mathrm{NaCl})$, Kalium iodida(KI) $5 \%$ dan Perak nitrat $\left(\mathrm{AgNO}_{3}\right)$ 0,02 N . 


\section{Prosedur penelitian}

\section{Pengolahan Sampel Secara Tradisional (PD)}

Rebung diambil kemudian dicuci lalu dirajang hingga berukuran kecil. Hasil rajangan tersebut dicuci kembali hingga bersih. Dididihkan air sebanyak $1 \mathrm{~L}$ kemudian di tambahkan garam dapur sebanyak $5 \mathrm{~g}$. Setelah itu, dimasukkan rajangan rebung ke dalam wajan yang telah berisi air mendidih masing-masing selama $5,10,15,20,30,60,90$,dan 120 menit lalu diangkat. Kemudian rebus kembali 5 menit, angkat lalu saring.

\section{Pengolahan Sampel Dengan Modern (AM)}

Rebung diambil kemudian dicuci lalu di rajang hingga berukuran kecil. Rajangan tersebut lalu dicuci dengan air mengalir selama 3 jam. Kemudian dilanjutkan dengan perebusan dengan air mendidih yang telah diberi garam dapur denga waktu $5,10,15,20,30,60,90$ dan 120 menit lalu diangkat.Kemudian rebus kembali 5 menit, angkat kembali lalu saring

Penetapan Kadar Sianida (AOAC, 1984)

Analisis kadar dilakukan dengan metode destilasi uap menurut AOAC (1984). Sebanyak $20 \mathrm{~g}$ sampel yang sudah dihaluskan ditaambahkan $100 \mathrm{ml}$ akuades dalam gelas kimia, dimaserasi selama 2 jam. Ditambahkan $100 \mathrm{ml}$ akuades kembali dilakukan destilasi uap. Destilat ditampung dalam erlenmeyer yang telah diisi $20 \mathrm{ml}$ $\mathrm{NaOH} 2,5 \%$. Setelah destilat mencapai $150 \mathrm{ml}$, destilasi dihentikan, ditambahkan 8 $\mathrm{ml} \mathrm{NH}_{4} \mathrm{OH}$ dan $5 \mathrm{ml} \mathrm{KI} 5 \%$, kemudian dititrasi dengan $\mathrm{AgNO}_{3} \quad 0,02 \mathrm{~N}$ sampai terjadi kekeruhan. Kadar HCN dihitung berdasarkan ketentuan $1 \mathrm{ml} \quad \mathrm{AgNO}_{3}$ ekuivalen dengan 0,54 HCN.

\section{Analisis Data}

Data yang di peroleh berupa angka bilangan kadar sianida yang terkandung pada rebung yang akan di analisa secara statistik dengan one way ANOVA. Jika perlakuan memberikan perbedaan yang singkat nyata akan dilakukan uji lanjut sesuai dengan nilai keseragaman. Serta hasil tersebut akan dibandingkan dengan nilai Standar Nasional Indonesia (SNI) yang ditetapkan oleh Badan Standarisasi Nasional (BSN).

$$
\left(\% \frac{b}{b}\right)=\frac{\text { Vtitran } \times \text { Ntitran } \times B E}{m \times 1000} \times 100 \%
$$

$$
\begin{aligned}
\text { Keterangan : Vtitran } & =\text { Volume titran } \\
\text { Ntitran } & =\text { Normalitas titran } \\
\mathrm{BE} & =\text { Berat ekuivalen } \\
\mathrm{m} & =\text { Berat Sampel }
\end{aligned}
$$

\section{HASIL DAN PEMBAHASAN}

Perbedaan penurunan kadar sianida dapat diketahui dengan menghitung selisih antara rata-rata kadar sianida setelah diberi perlakuan (kadar akhir) dengan kadar sianida dari rebung bambu ampel sebelum diberi perlakuan (kadar awal). Dimana kadar awal yang diperoleh dari rebung adalah sebesar 730 ppm. Berikut data penurunan kadar sianida ditampilkan pada Tabel 1 dan Gambar 1.

Perbedaan rata-rata penurunan kadar sianida berdasarkan kombinasi perlakuan sebagai berikut: 
Tabel 1 Rata-Rata Penurunan Kadar Sianida Berdasarkan Kombinasi Perlakuan

\begin{tabular}{|c|c|c|}
\hline \multirow[b]{2}{*}{$\begin{array}{l}\text { Waktu } \\
\text { (Menit) }\end{array}$} & \multicolumn{2}{|c|}{ Penurunan Kadar Sianida (ppm) } \\
\hline & $\begin{array}{l}\text { Perendaman \& } \\
\text { Perebusan } \\
\text { (PD) }\end{array}$ & $\begin{array}{c}\text { Air Mengalir \& } \\
\text { Perebusan (AM) }\end{array}$ \\
\hline 5 & $50,00 \pm 0,000$ & $\begin{array}{c}290,00 \\
\pm 20,000\end{array}$ \\
\hline 10 & $\begin{array}{c}106,00 \\
\pm 12,124\end{array}$ & $\begin{array}{l}386,67 \\
\pm 5,774\end{array}$ \\
\hline 15 & $\begin{array}{c}183,33 \\
\pm 11,547\end{array}$ & $\begin{array}{c}436,67 \\
\pm 25,167\end{array}$ \\
\hline 20 & $\begin{array}{l}290,00 \\
\pm 0,000\end{array}$ & $\begin{array}{c}486,67 \\
\pm 11,547\end{array}$ \\
\hline 30 & $\begin{array}{r}383,33 \\
\pm 5,774\end{array}$ & $\begin{array}{r}506,67 \\
\pm 5,774\end{array}$ \\
\hline 60 & $\begin{array}{c}446,67 \\
\pm 11,547\end{array}$ & $\begin{array}{c}563,33 \\
\pm 15,275\end{array}$ \\
\hline 90 & $\begin{array}{c}516,67 \\
\pm 11,547\end{array}$ & $\begin{array}{r}620,00 \\
\pm 0,000\end{array}$ \\
\hline 120 & $\begin{array}{c}580,00 \\
\pm 20,000\end{array}$ & $\begin{array}{r}656,33 \\
\pm 9,815\end{array}$ \\
\hline
\end{tabular}

Perbedaan rata-rata penurunan kadar sianida berdasarkan kombinasi perlakuan jika dilihat pada Gambar 1.
Penelitian ini bertujuan untuk mengetahui penurunan kadar sianida pada rebung dari varietas bambu lokal yakni ampel yang direbus pada berbagai variasi waktu dan cara pengolahannya sebelum di konsumsi. Rebung menjadi bahan makanan yang cukup digemari. Kegemaran tersebut beralasan karena dalam rebung terkandung nutrisi lengkap seperti protein, lemak, karbohidrat, vitamin $B_{1}, B_{2}, B_{3}$ dan $C$ serta mengandung unsurunsur mineral lain seperti riboflavin, niasin, thiamin, kalsium, fosfor, besi natrium, $\beta$ karoten dan serat (Soedjono dan Hartanto, 1994).

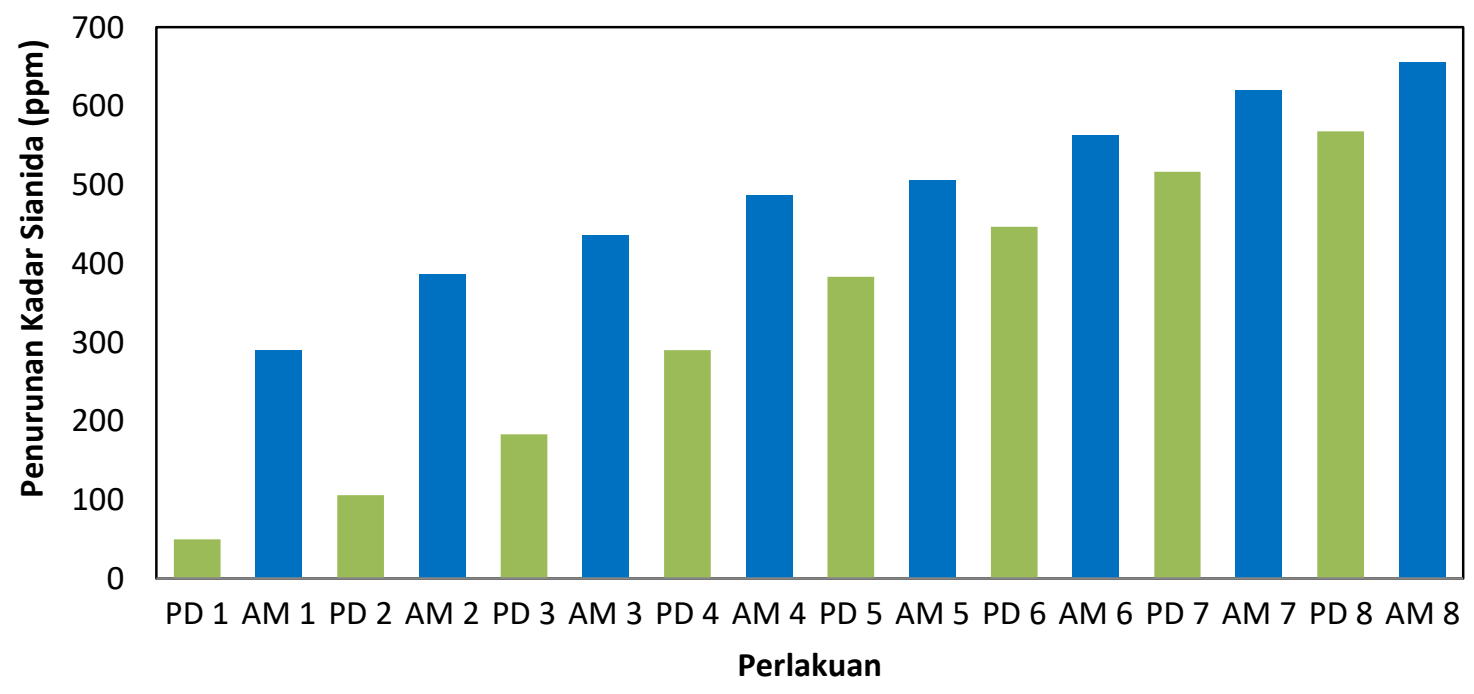

Keterangan :

$\begin{array}{llll}\mathrm{PD}_{1} & \text { : Perendaman } 5 \text { menit } & \mathrm{AM}_{1} & : \text { Air mengalir } 5 \text { menit } \\ \mathrm{PD}_{2} & \text { : Perendaman } 10 \text { menit } & \mathrm{AM}_{2} & : \text { Air mengalir } 10 \text { menit } \\ \mathrm{PD}_{3} & \text { : Perendaman } 15 \text { menit } & \mathrm{AM}_{3} & : \text { Air mengalir } 15 \text { menit } \\ \mathrm{PD}_{4} & \text { : Perendaman } 20 \text { menit } & \mathrm{AM}_{4} & : \text { Air mengalir } 20 \text { menit } \\ \mathrm{PD}_{5} & \text { : Perendaman } 30 \text { menit } & \mathrm{AM}_{5} & : \text { Air mengalir } 30 \text { menit } \\ \mathrm{PD}_{6} & \text { : Perendaman } 60 \text { menit } & \mathrm{AM}_{6} & : \text { Air mengalir } 60 \text { menit } \\ \mathrm{PD}_{7} & \text { : Perendaman } 90 \text { menit } & \mathrm{AM}_{7} & : \text { Air mengalir } 90 \text { menit } \\ \mathrm{PD}_{8} & \text { : Perendaman } 120 \text { menit } & \mathrm{AM}_{8} & : \text { Air mengalir } 120 \text { menit }\end{array}$

Gambar 1. Grafik Penurunan Kadar Sianida Berdasarakan Kombinasi Perlakuan 
Variabel respon dalam penelitian ini adalah kadar kadar sianida sedangkan faktor yang dicobakan ada 2 yaitu cara pengolahan serta waktu perebusan, di mana masing-masing faktor terbagi atas 2 taraf atau level. Cara pengolahan rebung sebelum direbus terdiri atas 2 taraf yakni cara perendaman dan cara di alirkan air mengalir. Waktu perebusan terdiri atas 8 taraf / level yaitu 5 menit, 10 menit, 15 menit, 20 menit, 30 menit, 60 menit, 90 menit dan 120 menit. Cara perendaman yang dimaksud adalah dengan merendam rebung yang dicuci dengan air.

Sampel yang digunakan pada penelitian ini adalah rebung bambu ampel kemudian disortasi basah yang bertujuan untuk memisahkan menghilangkan tanah dan zat-zat pengotoran lainnya yang melekat pada sampel. Proses selanjutnya dilakukan perajangan dengan tujuan agar kadar sianida terdapat pada rebung berkurang. Selanjutnya dilakukan proses pemasakan pada rebung dengan tujuan sianida dapat dikeluarkan dari rebung mentah dengan merusak jaringan melalui proses pemasakan (Salahudin, 2004).

Perebusan dapat menurunkan kadar sianida rebung bambu (Putra, 2009). Melalui pemanasan, enzim yang bertanggung jawab terhadap pemecahan linamarin menjadi inaktif dan hidrogen menyebabkan sianida tidak terbentuk (Winarno, 2002). Perebusan yang didahului dengan proses pencucian menyebabkan kadar sianida lebih rendah dibandingkan dengan perebusan yang tidak didahului dengan proses pencucian.

Sebelum dilakukan analisis kadar sianida dilakukan uji pendahuluan yaitu penetapan secara kualitatif untuk mengetahui berapa kadar awal sianida yang terdapat pada rebung sebelum perlakuan. Untuk penetapan kadar sianida, sampel dimaserasi menggunakan pelarut air bertujuan untuk menarik komponenkomponen kimia yang mudah larut dalam cairan penyari dengan sesekali pengadukan. Destilat kemudian ditampung dierlenmeyer lalu ditambahkan $\mathrm{NaOH}$ yang di lanjutkan dengan proses evaporator. Sebelum dilakukan analisis kadar sianida pada rebung, terlebih dahulu dibuat kurva baku larutan standararisasi $\mathrm{AgNO}_{3}$ 0,02 N untuk memperoleh normalitas atau konsentrasi larutan $\mathrm{AgNO}_{3}$ secara pasti. Karena pada proses pembuatan larutan $\mathrm{AgNO}_{3} \quad 0,02 \mathrm{~N}$ kemungkinan terjadi kesalahan sehingga diperoleh konsentrasi $\mathrm{AgNO}_{3}$ tidak murni yaitu konsentrasi $\mathrm{AgNO}_{3}$ yang tidak tepat $0,02 \mathrm{~N}$. Dari hasil penelitian, pada saat titrasi, hasil titrasi menunjukkan perubahan warna dari bening menjadi keruh dan apabila diamati pada dasar erlenmeyer terbentuk endapan. Perubahan warna dapat dijelaskan melalui reaksi berikut:

$$
\begin{aligned}
& \mathrm{CN}_{(\mathrm{aq})}+\mathrm{H}_{2} \mathrm{O}_{(\mathrm{aq})} \rightarrow \mathrm{HCN}_{(\mathrm{aq})}+\mathrm{O}_{2(\mathrm{aq})} \\
& \mathrm{HCN}_{(\mathrm{aq})}+\mathrm{NaOH}_{(\mathrm{aq})} \rightarrow \mathrm{NaCN}_{(\mathrm{aq})}+\mathrm{H}_{2} \mathrm{O}_{(\mathrm{aq})} \\
& \mathrm{NaCN}_{(\mathrm{aq})}+\mathrm{NH}_{4} \mathrm{OH}_{(\mathrm{aq})} \rightarrow \mathrm{NH}_{4} \mathrm{CN}_{(\mathrm{aq})}+\mathrm{NaOH}_{(\mathrm{aq})} \\
& \mathrm{NH}_{4} \mathrm{CN}_{(\mathrm{aq})}+\mathrm{KI}_{(\mathrm{aq})} \rightarrow \mathrm{NH}_{4} \mathrm{I}_{(\mathrm{aq})}+\mathrm{KCN}_{(\mathrm{aq})} \\
& \mathrm{KCN}_{(\mathrm{aq})}+\mathrm{AgNO}_{3(\mathrm{aq})} \rightarrow \mathrm{AgCN} \downarrow
\end{aligned}
$$


Berdasarkan hasil penelitian diketahui rata-rata kadar sianida dari rebung bambu ampel sebelum diberi perlakuan pada hasil pengukuran awal sebesar 730 ppm. Nilai tersebut digunakan sebagai kontrol perlakuan. Apabila kadar sianida pada rebung yang diberi perlakuan lebih kecil nilainya daripada kadar sianida sebelum diberi perlakuan (berfungsi sebagai kontrol positif) maka dapat dikatakan terjadi penurunan kadar sianida akibat perlakuan. Perbedaan penurunan kadar sianida dapat diketahui dengan menghitung selisih antara rata-rata kadar sianida setelah diberi perlakuan (kadar akhir) dengan kadar sianida dari rebung bambu ampel sebelum diberi perlakuan (kadar awal).

Dari hasil penelitian tampak bahwa penurunan kadar sianida yang paling besar terjadi akibat kombinasi perlakuan yaitu rebung yang dicuci dengan air mengalir dan direbus selama 120 menit. Kadar sianida yang dihasilkan oleh kombinasi perlakuan tersebut sebesar 68 ppm.

Dibandingkan dengan rebung yang masih mentah, rebung yang sudah direbus baik dengan cara perendaman maupun dengan alir mengalir memiliki kadar sianida lebih rendah dan signifikan dalam hal ini dengan tambahan garam dapur $\left(\mathrm{KIO}_{3}\right)$ diasumsikan dapat membantu menurunkan kadar sianida pada proses perebusan. Hal ini dibuktikan oleh output SPSS 16.0, dimana nilai $t_{\text {hitung }}=6,277>t_{\text {tabel }}=2,365$ atau nilai sig. $=0,000<\alpha=5 \%$. Adapun kriteria penolakan $\mathrm{H}_{0}$ jika $\mathrm{t}_{\text {hitung }}$ lebih besar daripada $t_{\text {tabel }}$ atau $p$-value lebih kecil dari taraf nyata $\alpha$. Oleh karena berdasarkan uji perbedaan diperoleh nilai $t_{\text {hitung }}>t_{\text {tabel }}$ atau nilai sig. $<\alpha=5 \%$ maka dapat disimpulkan tolak $\mathrm{H}_{0}$. Artinya ada perbedaan penurunan kadar sianida secara signifikan antara kedua cara pencucian sebelum rebung tersebut direbus.

Cara air mengalir lebih efektif menurunkan kadar sianida dibandingkan perendaman. Rebung yang dicuci dengan cara perendaman, kemungkinan kadar sianidanya masih banyak yang melekat pada saat penirisan air tersebut. Hal inilah yang menyebabkan rebung yang dicuci dengan air mengalir memiliki kadar kadar sianida lebih rendah.

Walaupun dengan pencucian terlebih dahulu sebelum perebusan dapat menurunkan kadar sianida rebung, namun kadar sianida rebung masak yang dihasilkan masih cukup tinggi, yaitu di atas 50 ppm (kadar sianida maksimal yang diijinkan menurut FAO), sehingga belum layak untuk dikonsumsi. Untuk itu perlu dilakukan penelitian lebih lanjut untuk menurunkan kadar sianida tersebut hingga memenuhi ketentuan. Salah satu alternatif yang mungkin bisa diteliti adalah dengan melakukan proses perebusan kembali kemudian di lanjutkan dengan proses perendaman secara bertahap mengingat sianida yang terkandung di dalam rebung masih cukup tinggi.

Hasil penelitian menunjukan bahwa perlakuan waktu perebusan menunjukan pengaruh yang nyata $(P<0,05)$ terhadap kadar sianida rebung bambu. Berdasarkan 
kadar sianida tertinggi terdapat pada perlakuan kombinasi air mengalir dan perebusan selama 5 menit yaitu sebesar 680 ppm dan terendah pada perlakuan kombinasi air mengalir dan perebusan selama 120 menit dengan kadar sianida yaitu 68 ppm. Semakin lama rebung direbus maka semakin baik untuk dikonsumsi karena akan menurunkan kadar sianida secara signifikan.

Hal ini menunjukkan perebusan rebung dalam air selama 120 menit dapat menurunkan kadar sianida secara nyata. Pada perebusan terjadi pelarutan sianida ke dalam air perebusan, dan ketika sisa air perebusan dibuang (ditiriskan) maka sianida ikut terbuang. Cara penurunan sianida dengan perebusan ini merupakan cara yang sederhana dan aman dilakukan, karena dalam penelitian tidak digunakan bahan-bahan tambahan seperti bahan kimia. Meski sianida yang terdapat pada beberapa jenis bahan pangan sebenarnya masih dapat dikatakan cukup aman asalkan dengan mengelolahnya secara tepat.

\section{KESIMPULAN}

Berdasarkan hasil penelitian dapat disimpulkan bahwa cara yang paling efektif untuk menurunkan kadar sianida sebelum dikonsumsi yaitu dengan kombinasi cara air mengalir kemudian dilanjutkan dengan perebusan dimana kadar sianida akhir diperoleh sebesar 68 ppm. Waktu yang paling efektif untuk penurunan kadar sianida pada cara pengolahan sebelum dikonsumsi yaitu pada waktu 120 menit perebusan.

Perlu dilakukan penelitian lebih lanjut untuk menurunkan kadar sianida dengan menggunakan variasi suhu, waktu alir dan proses pemasakan untuk mengetahui seberapa besar penurunan kadar sianida pada bahan pangan rebung. Selain itu, perlu menggunakan alat yang lebih akurat untuk menghitung kadar akhir sianida pada sampel seperti alat spektrofotometri.

\section{DAFTAR PUSTAKA}

Anonim. 2014. Bambu (bambusa vulgaris Schrad). http://plantamor.com. Di akses pada tanggal 8 April, 2015.

[AOAC] Analysis of The Association of Official Agriculture Chemistry. 1995. Official Methods of Analysis, 16th Edition. Gaithersburg, Maryland: AOAC International.

Kanchan R., C., Nirmala, M. S. Bisht., 2015. Processing Techniques for Reduction of Cyanogenic Glycosides from Bamboo Shoots. Food and Pharmaceuticals' Prosiding $10^{\text {th }}$ World Bamboo Congress. Korea.

Pambayun R. 2007. Kiat Sukses Teknologi Pengolahan Umbi Gadung. Yokyakarta: Ardana Media.

Putra I N K. 2009. Efektifitas Berbagai Cara Pemasakan Terhadap Penurunan Kandungan Asam Sianida Berbagai Jenis Rebung Bambu. AGROTEKNO.15 (2): 40- 42.

Salahudin. 2004. Kajian Fermentasi Cangkuk dari Daging Sapi dan Rebung Bambu Betung (Dendrocalamus asper). Tesis. Bogor: Program Pascasarjana. Institut Pertanian Bogor.

Schmitz G., Lepper H., Heidrich M. 2004. Farmakologi dan toksikologi. Jakarta: EGC.

Soedjono, Hartanto. 1994. Budidaya Bambu. Semarang: Dahara Prize.

Winarno, F.G., 2002. Kimia Pangan dan Gizi. Jakarta: Gramedia Pustaka Utama, 